\title{
LXXVIII. On the thermo-electric spark
}

\section{Wheatstone Esq. F.R.S.}

To cite this article: C. Wheatstone Esq. F.R.S. (1837) LXXVIII. On the thermo-electric spark, Philosophical Magazine Series 3, 10:62, 414-417, DOI: 10.1080/14786443708649182

To link to this article: http://dx.doi.org/10.1080/14786443708649182

册 Published online: 01 Jun 2009.

Submit your article to this journal $\pi$

Џ Article views: 3

Q View related articles $\sqsubset$ 


\section{Prof. Wheatstone on the Thermo-electric Spark, \&c.}

hitherto discovered is more ancient than the oldest stratified formations known to us; we cannot even decide the relations in pirint of age of the most ancient granite to the oldest fossiliferous beds.

But why, I may ask, should man, to whom the early history of his own species and the rise of nations presents so obscure a problem, feel disappointed if he fail to trace back the animate world to its first origin? Already has the beginning of things receded before our researches to times immeasurably distant. Why then, after wandering back in imagination through a boundless lapse of years, should we expect to find any resting-place for our thoughts, or hope to assign a limit to the periods of past time throughout which it has pleased an omnipotent and eternal Being to manifest his creative power?

But it is not my intention to advert now to these and other points on which $I$ happen to differ from Dr. Buckland. I would rather express the gratification $I$ feel in finding myself in perfect accordance with him on so many subjects. His work is admirably adapted to convey instruction on organic remains, and other departments of geology, both to beginners and to those well versed in the science, and is characterized throughout by a truly philosophical spirit, which betrays no desire to adhere tenaciously to dogmas impugned or refuted by the modern progress of science. On the contrary, the author has abandoned several opinions which he himself had formerly advocated; and although still attached to the theory which teaches the turbulent condition of the planet when the lias and other fossiliferous rocks were formed, and the general insufficiency of existing causes to explain the changes which have occurred on the earth, he yet refers in almost all parts of his book to the ordinary operations of nature to explain a variety of phænomena once supposed to be the result of causes different in kind and degree from those now acting.

I have now, Gentlemen, only to offer you my acknowledgements for the high honour conferred upon me by my election to fill the President's chair for the last two years; and it is a source of great satisfaction to me to feel assured of the continued prosperity and usefulness of the association when I resign my trust into the hands of a successor so distinguished for his zeal, talents, and varied acquirements as Mr. Whewell.

LXXVIII. On the Thermo-electric Spark, \&c. Communicated by C. Whea'tstone, Esq., F.R.S., Professor of Experimental Philosophy in King's College, London.

THE following notice of some recent experiments made in Italy, on the production of the thermo-electric spark, and on the chemical effects of the thermo-electric currents, will, no doubt be acceptable to many of your readers. I shall 
confine myself to a simple statement and corroboration of the facts, avoiding all theoretical considerations.

The Cav. Antinori, Director of the Museum at Florence, having heard that Prof. Linari, of the University of Siena, had succeeded in obtaining the electric spark from the torpedo by means of an electro-dynamic helix and a temporary magnet, conceived that a spark might be obtained by applying the same means to the thermo-electric pile. Appealing to experiment his anticipations were fully realized. No account of the original investigations of Antinori has yet reached this country, but Prof. Linari, to whom he early communicated the results he had obtained, immediately repeated them, and published the following additional observations of his own in L'Indicatore Sanese, No. 50, of Dec. 13, 1836.

" 1 . With an apparatus consisting of temporary magnets and electro-dynamic spirals, the wire of which was 505 feet in length, he obtained a brilliant spark from a thermo-electric pile of Nobili's construction consisting only of 25 elements, which was also observed in open daylight.

" 2. With a wire 8 feet long coiled into a simple helix, the spark constantly appeared in the dark, on breaking contact, at every interruption of the current; with a wire 15 inches long he saw it seldom, but distinctly; and with a double pile; even when the wire was only 8 inches long. In all the abovementioned cases the spark was observed only on breaking contact, however much the length of the wire was diminished.

" 3 . The pile consisting merely of these few elements, and within such restricted limits of temperature as those of ice and boiling water, readily decomposed water. Short wires were employed having oxidizable extremities; the hydrogen was sensibly evolved at one of the poles.

"4. A mixture of marine salt moistened with water and of nitrate of silver being placed between two small horizontal plates of gold, communicating respectively with the wires of the pile, the latter after having acted on the mixture gave evident signs of the appearance of revivified silver on the plate which was next the antimony.

"5. An unmagnetic needle placed within a close helix formed by the wire of the circuit became well magnetized by the current.

"6. Under the"action of the same current the phænomenon of the palpitation of mercury was distinctly observed."

The interesting nature of these experiments induced me to attempt to verify the principal result. The thermo-electric pile I employed consisted of 33 elements of bismuth and an- 


\section{Prof. Wheatstone on the Thermo-electric Spark, \&c.}

timony formed into a cylindrical bundle $\frac{3}{4}$ of an inch in diameter and $1 \frac{1}{5}$ inch in length; the poles of this pile were connected by means of two thick wires with a spiral of copper ribbon 50 feet in length and $1 \frac{1}{2}$ inch broad, the coils being well insulated by brown paper and silk. One face of the pile was heated by means of a red-hot iron brought within a short distance of it, and the other face was kept cool by contact with ice. Two stout wires formed the communication between the poles of the pile and the spiral, and the contact was broken, when required, in a mercury cup between one extremity of the spiral and one of these wires. Whenever contact was thus broken a small but distinct spark was seen, which was visible even in daylight. Professors Daniell, Henry, and Bache assisted in the experiment, and were all equally satisfied of the reality of the appearance.

At another trial the spark was obtained from the same spiral connected with a small pile of 50 elements, on which occasion Dr. Faraday and Prof. Johnston were present, and verified the fact. On connecting two such piles together so that the similar poles of each were connected with the same wires, the same was seen still brighter*.

I conclude, therefore, that the experiment of Antinori is a real addition to our knowledge of electrical phænomena, and though it was far from being unexpected, it supplies a link that was wanting in the chain of the experimental evidence which tends to prove that electricity, from sources however varied, is similar in its nature and effects, a conclusion rendered more than probable by the recent discoveries of Faraday. The effects thus obtained from the electric current originating in the thermo-electric pile may no doubt be easily exalted by those who have the requisite apparatus at their disposal. It is not too much to expect, seeing the effects produced by a pile of such small dimensions, that by proper combinations the effects may be exalted to equal those of an ordinary voltaic pile.

I shall close this hasty communication with a notice of some experiments on the chemical action of the thermo-electric pile made earlier by Prof. G. D. Botto, of the University of Turin. The form of the pile he employed may suggest some useful hints to those who are inclined to continue the inquiry, as it. admits of the application of much higher degrees of heat than one of the ordinary construction does, though the difference of the thermo-electric relations of the two metals employed is not street.

- The two piles here employed were made by Mr. Newman of Regent- 
so considerable. Prof. Botto's experiments were published in the Bibliothèqu Universelle for September 1832, and I am not aware that they have yet been published in any English Journal. The thermo-electric apparatus was a metallic wire, or chain, consisting of 120 pieces of platinum wire, each one inch in length and $\frac{1}{10} \overline{0}$ th of an inch in diameter, alternating with the same number of pieces of soft iron wire of the same dimensions. This wire was coiled as a helix round a wooden rule 18 inches long, in such a manner that the joints were placed alternately at each side of the rule, being removed from the wood at one side to the distance of four lines. Employing a spirit-lamp of the same length as the helix, and one of Nobili's galvanometers, a very energetic current was shown to exist; acidulated water was decomposed, and the decomposition was much more abundant when copper instead of platinum poles were used: in this case hydrogen only was liberated. The current and decomposition were augmented when the joints were heated more highly. Better effects were obtained with a pile of bismuth and antimony, consisting of 140 elements bound together into a parallelopiped, having for its base a square of two inches, three lines, and an inch in height.

King's College, April 24, 1837.

\section{Intelligence and Miscellaneous Articles.}

\section{ATHEREAL OIL OF WINE. LIEBIG AND PELOUSE.}

$\mathbf{I}^{\mathrm{T}}$ $\Gamma$ is well known that a mix ture of alcohol and water in the same proportions as they exist in wine has scarcely any odour, whilst a few drops of wine remaining in a bottle will be easily recognised by its smell. This characteristic odour, which is possessed by all wines in a greater or less degree, is produced by a peculiar substance, which has all the characters of an essential oil. This substance is not to be confounded with the aroma of wine; for it is not volatile, and appears to be different in various kinds of wine, and in the greater number it does not exist at all.

When large quantities of wine are submitted to distillation, an oily substance is obtained towards the end of the operation; it is also procured from wine lees, and especially from that which is deposited in the casks after fermentation has commenced.

This æthereal oil forms about one $40,000 \mathrm{dth}$ part of wine. In its original state it has a strong flavour, is usually colourless, but owing to the presence of a small portion of oxide of copper it is sometimes greenish : when this is separated by hydrosulphuric acid it is colourless. The mode of purifying this substance will be mentioned after its composition and principal properties have been described.

This æhereal oil of wine contains a considerable quantity of oxyThird Series. Vol. 10. No. 62. May 1837. 